\title{
Expanding socio-economic considerations in the management of New Brunswick's Crown land forests
}

\author{
by Michael I.L. Kennedy', Thomas M. Beckley² and Van A. Lantz ${ }^{2}$
}

\begin{abstract}
New Brunswick is in the midst of a forest policy debate regarding wood supply. This paper outlines the historical context, presents recent data and provides a detailed update on policy activities related to this debate. In 2004, the bi-partisan Legislative Select Committee on Wood Supply produced a report complete with recommendations for action. We report on the provincial government response to those recommendations, which has been to: broaden public input into forest management and planning; broaden the range of forest values considered in forest management/policy; and employ new tools, indicators and analysis to provide information to policy-makers.
\end{abstract}

Key words: New Brunswick, wood supply, Crown land policy history, policy debate, socio-economic indicators, public participation in forest management

\section{RÉSUMÉ}

Le Nouveau-Brunswick vit actuellement un débat portant sur les politiques forestières rattachées à l'approvisionnement en matière ligneuse. Cet article souligne le contexte historique, présente les données récentes et effectue une mise à jour détaillée des activités touchant les politiques impliquées dans ce débat. En 2004, le comité créé par les élus provinciaux sur l'approvisionnement en matière ligneuse a produit un rapport complet comprenant des recommandations à mettre en œuvre. Nous faisons état de la réponse du gouvernement provincial relativement à ces recommandations qui visaient à : accroître la participation du public en matière d'aménagement forestier et de planification forestière, élargir le domaine des valeurs forestières retenues en aménagement forestier et en matière de politique et l'utilisation de nouveaux outils et indicateurs ainsi que de récentes analyses pour fournir de l'information aux concepteurs de politiques.

Mots clés : Nouveau-Brunswick, approvisionnement en matière ligneuse, historique des politiques des terres publiques, débat sur les politiques, indicateurs socio-économiques, participation du public en aménagement forestier

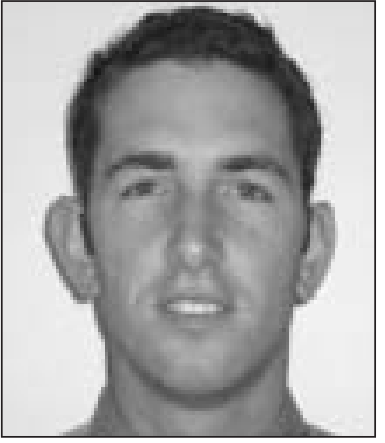

Michael I.L. Kennedy

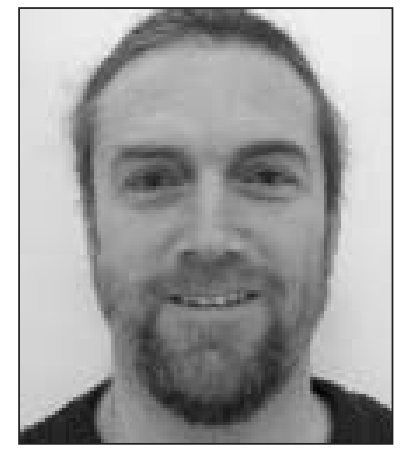

Thomas M. Beckley

\section{Introduction}

A transition is underway in the management of Crown land forests in New Brunswick. The transition has emerged over the past decade as an increasingly educated and socially aware public has demanded a more diverse stream of benefits from its forest resource (Erdle 1998). This has resulted in a significant amount of friction in the political sphere where the interests of the forest industry have been colliding with those of other special interest groups. Not since the debate over spruce budworm spraying (circa 1976) has the New Brunswick public been so concerned about forest management policies in the province.

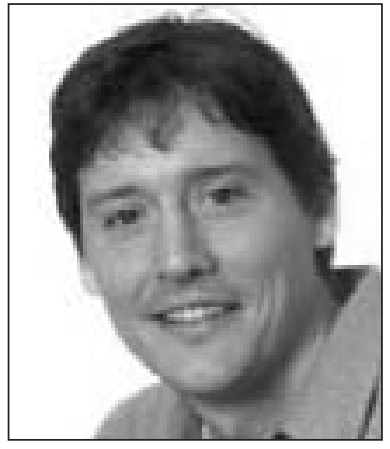

Van A. Lantz
The most recent debate began in late 2001, when the New Brunswick Forest Products Association (NBFPA) submitted a letter to Jeannot Volpé, then Minister of Natural Resources, lobbying the government to: (i) increase the harvest from Crown land, (ii) intensify current management to invoke a doubling of future wood supply, and (iii) revise non-timber goals to facilitate the harvest increase. This letter set off a chain of events within the New Brunswick political arena that has increased public concern related to the future of forest management in the province, and led to a number of reforms and new policy initiatives within the provincial government.

While the current debate began over the issue of fibre supply, it has ultimately mushroomed into a much wider discussion surrounding public participation in the forest management planning process, value-added production, community forestry, the adequacy or necessity of current conservation measures, and the proper roles and responsibilities for government and industry in forest management on Crown land, among others (LANB 2004).

\footnotetext{
1Pembina Institute, 2nd Floor, 10008 - 82 Avenue, Edmonton, Alberta T6E 1Z3. Corresponding author. E-mail: mikek@pembina.org.

${ }^{2}$ Faculty of Forestry and Environmental Management, University of New Brunswick, P.O. Box 44555, Fredericton, New Brunswick E3B 5A3.
} 
The purpose of this paper is to contribute to the debate over Crown land management in New Brunswick by: (i) providing an historical context of forest management policy in the province; and (ii) analyzing the extent to which current policies can (and are being) adapted to incorporate a more diverse set of social and economic considerations.

The paper is organized as follows. In the next section we provide a review of relevant historical events that have contributed to the current state of forest management policies on Crown land in New Brunswick. Then, in the third section, we examine the extent to which socio-economic indicators can (and are being) incorporated into Crown land forest management planning in the province. In the fourth section, we provide an analysis of other social commitments made by the provincial government and the extent to which they have been implemented. The final section concludes with a discussion about what to expect in the near future.

\section{Historical Context of Forest Management Policy on Crown Land in New Brunswick Pre-1970s}

One of the largest spruce budworm outbreaks on record drove policy and management of New Brunswick's forests throughout the 1950s (Baskerville 1995). This outbreak represented one of three that occurred in Canada in the $20^{\text {th }}$ century. The three main events occurred in the 1910s, 1940s and the 1970s and resulted in significant tree mortality and damage. These events occurred across Canada and are estimated to have affected 11, 25 and 58 million hectares respectively. This outbreak resulted in the loss of some 81 million to 107 million $\mathrm{m}^{3}$ of fibre across Canada (Maclean et al. 2001, 2002). This disturbance event resulted in significant change to the forest age class structure and subsequently to the productivity of the forest (Maclean et al. 2001).

\section{0s}

The impetus for the contemporary debate over Crown land management in New Brunswick can be marked by two key issues-the public debate over the spraying of New Brunswick forests to reduce the impact of the spruce budworm outbreak (Baskerville 1976) and the purchase of private woodlot owner's timber for use in the Crown land Licensees' mills. These two issues form the basis of the current debate in the province regarding the future of Crown land management as they juxtapose the increasing concern over the environmental well-being of the forest and its ability to provide economic benefits to the public of New Brunswick. More specifically, the biophysical ramifications of the spruce budworm outbreak, in terms of changing the age class structure of the Crown land forest, are being dealt with today and this is one of the underlying reasons for the forest industry's request for an increased investment in wood fibre production into the future.

The need to better understand current and future wood supplies led to the development of forest estate forecasting models. In the beginning, these were onerous and very programming-intensive. The initial wood supply model (FORMAN) enabled managers to better understand the status of wood supply in the province. During this period of rapidly increasing knowledge regarding forest ecosystem dynamics and timber supply, the future low point in the operable growing stock profile of the province was predicted to occur in
2012 (Baskerville 1976). From the 1970s onward, everyone in the forestry community knew that timber shortages were likely, if not inevitable, by the second decade of the $21^{\text {st }}$ century.

Due to the concern for future wood supplies, the industry and government advocated increases in the investment in silvicultural activities and the further establishment of planting and precommercial thinning trials. The aim of the silvicultural activities was to increase future production of wood volume and to shorten the rotations for commercial timber.

\section{2}

The concern over Crown land management and resource use culminated in the creation of New Brunswick's Crown land and Forest Act (NBCLFA) which was passed into law in 1982 (NBDNR 1982). The NBCLFA set forth the parameters for the development of industrial forestry as it is currently practised on Crown land in New Brunswick. The Act stated that, in order to become a Crown land Licensee, companies had to own a manufacturing facility within the boundaries of the Crown License. The Act also stipulated that the province would provide Licensees with credit to conduct silvicultural practices aimed at enhancing the yield of the forest resource (Baskerville 1995). The intent of the NBCLFA was to give Licensees the primary role in developing and implementing management plans for Crown land, with government forestry staff being relegated to the role of overseer.

\section{0}

Over the course of the 1980s and 1990s, the elements included in forest management plans were reviewed every five years and significant revisions were made. Some of the changes stipulated withdrawals of forest land from the total area of Crown land available for timber harvest. Other changes created new operational constraints on Licensees so as to provide a number of other benefits from the forest. Among these were protection of deer wintering areas, old spruce-fir habitat, ecological reserves, and an allocation of $5 \%$ of Crown timber to Aboriginal groups. These were created in response to pressure from various segments of society (deer hunters, the environmental community, First Nations). As time passed the repercussions of industrial-type management on Crown land were coming to bear on the provincial government with concerns from the public over perceived environmental degradation occurring in the Crown forest from intensive forest management. The concerns expressed by the general public, environmental non-government organizations (ENGOs) in their infancy, and the Department of Environment spurred the provincial government to establish the New Brunswick Roundtable on the Environment and Economy (NBREE). The role of NBREE was to examine, among other things, the course of action to take to put the Crown land forest sector on a more benign environmental path. The NBREE set forth guidelines for forest managers in the province to enhance buffer and riparian areas in hydrologically sensitive areas.

\section{9}

In 1999, after years of discussions and the commissioning of a scientific study to identify candidate sites, public hearings were held regarding the establishment of protected areas for the province. The hearings demonstrated that the New 
Brunswick public supported the conservation of biodiversity and key landscape features (NBDNR 1999). The resulting policy implications of these hearings and the establishment of the protected area plan was that 150000 hectares of Crown land was taken out of production (NBDNR 2003). Analysis by Gardner Pinfold Consulting (2000) estimated that the resulting wood supply reduction caused as many as 565 job losses, $\$ 2.4$ million in annual royalty losses, $\$ 18.6$ million in income losses, and almost $\$ 60$ million in annual losses in manufactured output.

At the same time as the protected areas were being established, the government was fortuitously able to purchase 150 000 ha of industrial freehold forest. This "new" Crown land was made available to existing license holders and while this appeased industry in the short term, they still felt vulnerable to future random and unpredictable reductions in their fibre supply. This set the stage for the next public debate on Crown land forest management.

\section{2}

With ever-tightening environmental constraints being imposed on them, people in the forest industry began to feel they were losing control and security of access to the fibre supply they needed to convince creditors to continue to finance their operations. In response, the forest industry decided to contract Jaakko Pöyry (JP) Consulting to investigate the opportunities that existed for increasing the competitiveness of the forest industry in the province. The government co-sponsored the report (i.e. shared the costs) so that the methods and results could be made public. The JP report concluded that the government could indeed improve industry competitiveness by implementing a more intensive forest management regime through the use of forest plantations, increased harvesting in pre-established special management zones (e.g., stream buffers, deer wintering areas), and increased control by licensees over the management of Crown land resources (JP 2002). The report authors estimated that such efforts would eventually double the annual allowable cut on Crown land in the province within the next 40 years-an estimate produced by aggregating wood supply information given to JP from each Crown land licensee. ${ }^{3}$ Despite the fact the report also covered areas such as public involvement, administerial overlap (between government and industry), conservation on private land, and research, public outcry focused on the recommendations around wood supply and the institutional framework for managing Crown land. Environmental and other interest groups argued that such an intensive volume-based strategy would re-institute a "fibrefirst" management scenario and reduce the ability of the forest to provide sufficient non-timber values, which had been recognized as important and protected by various measures over the previous two decades.

While the report claimed that the additional fibre could be obtained without any significant environmental degradation, there was no systematic assessment of socio-economic impacts associated with different management scenarios in the initial JP report. In order to rectify this oversight, the New

\footnotetext{
${ }^{3}$ It is unclear in the JP report how the wood supply estimates were generated by licensees. However, in most cases it is likely that the estimates were produced from individual licensee wood supply model runs.
}

Brunswick Forest Products Association contracted the Atlantic Provinces Economic Council (APEC) to produce a report on the potential economic impact of the strategy proposed in the JP report. The APEC report used an input-output model of the provincial economy together with a number of simplifying assumptions regarding forest sector impacts of timber supply changes to examine the long-term gross domestic product (GDP) and employment impacts under business-as-usual versus intensive forest management strategies proposed in the JP report. The report authors concluded that GDP and employment would increase by $17 \%$ and $11.7 \%$, respectively, over the 2002-62 period under the intensive volume-based relative to the business-as-usual strategy (APEC 2003).

\section{3}

The ensuing public debate over the JP report resulted in the New Brunswick government creating a Legislative Assembly Select Committee on Wood Supply (LSCWS) composed of elected officials (Members of the Legislative Assembly). As well, New Brunswick Department of Natural Resources (NBDNR) staff and two outside experts were retained to support the Committee and to help them interpret the views and recommendations from the public and special interest groups concerning the management of Crown land in New Brunswick. Public hearings were scheduled for around the province to solicit input on the report. Presenters made their appeals directly to the panel of MLAs and the technical support team. Demand for space at the public hearings far surpassed what was expected and ultimately the number of hearings was doubled to accommodate all the interest. Ultimately, over 200 stakeholders and members of the public made presentations to the LSCWS. There were also 131 written submissions. The LSCWS also solicited information from various experts following the public hearings in order to obtain more detailed information regarding topics and policy options presented in the hearings. In all, the public hearings represent what is likely the most open and complete public airing of forestry perspectives in the history of New Brunswick (Erdle and MacLean 2005).

\section{4}

The LSCWS produced a report that summarized the input of the public hearings and expert interviews held throughout the previous year. The report featured a number of recommendations for the government to consider in the management of Crown land in the province (LANB 2004). In total, the report contained 25 recommendations-nine in the theme of Governance and Accountability, five in Forest Management Objectives, six related to Allocation of Resource and Distribution of Benefits, and five concerning Provincial Wood Supply.

Unfortunately, the day before the LSCWS report was released, the St. Anne-Nackawic pulp mill announced it was closing, and five days after the report, UPM Kymmene in Miramichi announced the permanent closure of its kraft mill. The forest sector was certainly the front page news, but much of the media attention was diverted away from long-term solutions embodied in the LSCWS report to the short-term crisis around mill closures. 
2005

In April, the provincial government crafted a response to the LSCWS report. Part of the response was the formation of a Forestry Task Force headed by Dr. Thom Erdle. "The mandate of the Task Force is to develop a broad set of realistic forest management alternatives, which achieve the goals of establishing wood supply objectives for all commercial species while retaining the characteristics of the Acadian forest. The Task Force will also provide key information that will be used to assess forest management alternatives in environmental, social and economic terms" (NBDNR 2005a). An important aspect of the Task Force's work will entail expanding the set of socio-economic indicators used in the evaluation of forest management strategies.

\section{Incorporating Socio-Economic Indicators in Forest Management Planning}

There are a large number of socio-economic indicators that can be used when examining the impacts of forest management plans or strategies. A host of countries and forest certification schemes have developed unique sets of socio-economic "Criteria and Indicators" for use as measurements of some form of overall sustainable forest management (Adamowicz 2003). Socio-economic indicators traditionally considered include gross domestic product (GDP), employment and associated earnings, government revenues, demand and supply of public services, and measures of natural capital (including recreation facilities, wildlife habitats, resourcebased tourism, and other ecosystem services).

The indicators selected for assessment typically fall into one of two categories - primary or secondary. Often, primary indicators reflect a management objective and are given priority (or the highest weight) in the list of indicators that are used for assessing socio-economic impacts of management alternatives.

Socio-economic indicators have been measured in the past using a number of techniques developed by sociologists and economists. Economists have developed various market and non-market techniques to measure such indicators. Market techniques use the existing market conditions, or surrogate markets, to help express an indicator in dollar terms. Nonmarket techniques often use constructed or hypothetical markets to express an indicator in dollar terms.

Sociologists typically use a mix of quantitative and qualitative analysis to help measure socioeconomic indicators. Surveys are often used to elicit the public's values and beliefs. This is done by questioning respondents on preferences regarding forest management and/or policy. In many cases questions are structured as rankings, ratings, or scales (such as strongly agree, agree, neither agree nor disagree, disagree, strongly disagree) so that quantitative analysis of the data may follow. In this case, ordinal indicators can then be determined after conducting some statistical analysis (Beckley et al. 2002).

The New Brunswick Task Force has been working over the past year to develop a list of socio-economic indicators to be used in their assessment of forest management alternatives on Crown land in the province. In the spring of 2006, a focus group consisting of a diverse set of stakeholders was organized by the Task Force to discuss which socio-economic indicators should be considered. Upon review, the Task Force gave special attention to the following measurable indicators (among others): stumpage revenues, shipment values of pri- mary forest products, contribution to GDP, contribution to Genuine Progress Index (GPI), revenue retained locally, robustness to market swings, levels and type of employment opportunities, and contribution to natural capital. Some of these indicators (such as stumpage revenues and shipment value of primary forest products) are relatively easy to measure and would fit nicely into the standard wood supply modeling framework used by the Department of Natural Resources. Other indicators (such as GPI, and contribution to natural capital), however, are not so easily measured and require independent studies using social and/or economic techniques mentioned previously. As such, the Task Force will likely decide to limit their analysis to those indicators that fit within the scope and time line of their mandate, which is expected to be completed by the end of 2007 .

Foreshadowing the type of report that the Task Force is likely to produce (albeit in a less extensive way), a recent study by Kennedy et al. (2007) has investigated the impact that alternative Crown land forest management strategies might have on forest and economic indicators within New Brunswick. In this article, four alternative forest management strategies were considered: (i) a business-as-usual (BAU) strategy, where the objective was to maximize spruce-pine-fir volume with the existing silviculture budget maintained by the government; (ii) an intensive (INT) strategy, where the objective was to maximize spruce-pine-fir volume without any budget constraint on silvicultural investments; (iii) a GDP-focused (GDP) strategy, where the objective was to maximize the present value of forest manufacturing sector contribution to GDP, using a $4 \%$ discount rate and without a budget constraint on silvicultural investments; and (iv) a government-focused (GOV) strategy, where the objective was to maximize present value royalties minus silviculture expenditures (defined as government surplus), using a 4\% discount rate and without a budget constraint on silvicultural investments. It is interesting to note here that the INT strategy defined by the authors follows closely the model used in the JP report.

Kennedy et al. (2007) defined their forest management strategies within an extended wood supply model of unconstrained Crown land that incorporated both forest and economic indicators over an 80-year planning horizon. Forest indicators examined included: operable growing stock; softwood and hardwood harvest levels; and silvicultural treatments such as full-planting, fill-planting, and precommercial thinning. Economic indicators examined included: present value logging, lumber, and pulp sector shipment values; present value licensee and government costs, royalties, and net surplus from Crown forest management; and present value lumber, pulp and total manufacturing sector contribution to GDP (computed using input-output multipliers).

Results of the forest indicator analysis showed that, under the INT strategy, the provincial Crown land softwood harvest level would double within the next 70 years, increasing from just under 20 million cubic meters $\left(\mathrm{Mm}^{3}\right)$ in the 2002-2007 planning period to just under $40 \mathrm{Mm}^{3}$ in the 2068-2073 planning period. Similarly to the findings in the JP report, Kennedy et al. (2007) found that the doubling of the harvest level would result largely from increases in planting levels early on in the planning horizon and increases in precommercial thinning levels in later periods. Surprisingly, however, Kennedy et al. (2007) found that similar harvest level 
increases would emerge under the BAU strategy, where the softwood harvest level would increase from just under 20 $\mathrm{Mm}^{3} /$ period to just under $35 \mathrm{Mm}^{3} /$ period. This finding tends to weaken the argument put forth by the JP report that additional large silvicultural investments are needed to increase the wood supply.

The GDP and GOV strategies considered in the Kennedy et al. (2007) article resulted in a focus being placed on hardwood harvesting, thereby capitalizing on higher-valued products. Interestingly, while the GDP strategy also produced an almost doubling of the softwood harvest level over the planning horizon, the GOV strategy produced a relatively constant (slightly declining) harvest level, indicating that much of the silvicultural investment in the other strategies would not pay off from the government's perspective.

Results of the economic indicator analysis showed that, as expected, the GDP strategy exceeded the net present value contribution of the other strategies (ranging from $\$ 4.3 \mathrm{~B}$ to $\$ 2.7 \mathrm{~B}$ more) over the 80 -year planning horizon. Likewise, the GOV strategy exceeded the government surplus produced by the other strategies (ranging from $\$ 351.5 \mathrm{M}$ to $\$ 168.8 \mathrm{M}$ ) over the same period. Logging sector profit levels were found to be relatively the same over all strategies, with differences amounting to at most $\$ 47$ million).

Overall, the study undertaken by Kennedy et al. (2007) sheds light on a number of important issues that need to be considered for forest management planning. Some of the issues include the relationships and trade-offs that exist between forest and economic indicator performance, the degree to which different forest management strategies impact the future profile of the forest, and how the forest responds to different forest management strategies in the present and in the future. While the indicators used in this study were restricted to a certain set of forest and economic variables, they by no means represent an exhaustive compilation. This type of analysis can be used to examine a broader suite of indicators, which will likely be seen within the Task Force report. Such a suite of indicators will no doubt help the policy-makers bring further transparency to the realities of the impacts that forest management strategies have on the forest, the economy, and communities.

\section{Other Social Commitments Made By the Provincial Government}

The recent events in forest policy development in New Brunswick may well have changed the policy-making landscape in the province for the foreseeable future. Fully nine of the 25 recommendations of the LSCWS had to do with government accountability. The Tory government in power at the time the report was issued committed to action on four of the nine recommendations. While the Liberal opposition was vocal in its criticism of the government's response to the report, the new Liberal government in power since the fall of 2006 is continuing to implement many of the initiatives that were started under the previous government.

Many of the recommendations have to do with how the public and/or stakeholders are integrated into the forest planning and management process. For example, among the nine recommendations are the following (LANB 2004):

1) That, by December 2007, NBDNR prepare a strategy for public participation, in time for 2012 management plan development.
2) That, no later than April 2005, a Provincial Advisory Committee be established to provide advice to the Minister of Natural Resource on issues pertaining to Crown forest management.

3) That NBDNR incorporate the Select Committee recommendations adopted as result of this report into Departmental policies, the 2007 and 2012 Vision documents, and the Forest Management Manual, where appropriate.

4) That, effective 2005, the Minister of Natural Resources report annually to the Legislature on the status of New Brunswick's forest and its management.

5) That a public participation process similar to the one just completed by the Select Committee be undertaken on a 10-year cycle.

6) That as soon as possible, the purpose and function of the Licensee Stakeholder Committees be clarified and enhanced.

In May of 2006, the government in power made explicit commitments regarding the first four recommendations. In November 2005 the inaugural meeting of the Minister's Provincial Advisory Committee was held and several meetings have been held subsequently. The committee is comprised of a diverse range of stakeholders that represent industry (large and small), wildlife groups, environmental groups, woodlot owners, academics and the research community (NBDNR 2005b).

In December 2005, the Minister of the Department of Natural Resources presented the first Annual State of the Forest report to the provincial legislature. A second report was completed for 2006 and this reporting is now a normal part of business for NBDNR (2006).

As well, the Department has committed to a thorough review of public involvement for Crown land management. One experiment is already underway - a province-wide random sample survey of New Brunswickers on their attitudes and views of the province's management of Crown land, their preferences for future public involvement opportunities, and basic measures of respondents' forest values. Results from this survey and other consultations with stakeholders will help guide NBDNR officials in formulating strategies to address items five and six above (NBDNR 2007).

\section{Discussion and Conclusion}

There remains a debate in New Brunswick about whether or not the Crown lands and Forest Act, now 25 years old, is a robust yet flexible enough policy instrument to effectively respond to the changes and challenges in contemporary forest management. The forest industry is in crisis at the national level due to many factors that are outside provincial policymakers' control. The forest industry continues to argue that if it had better access to more and cheaper fibre that it could continue to compete in international markets. Federal and provincial governments have stepped forward with various support packages. Whether these are targeted at the right issues, and whether they can even make a significant difference in light of the challenges remains to be seen. Many stakeholder groups and citizens are sceptical of industry's claims that solvency is right around the corner with a little more help. Short-rotation, southern fibre is coming online in numerous countries that have cheap labour and lax environmental laws. Short-term fixes by governments are not likely to 
address such long-term structural changes in the global forest products industry. Given that, some interests continue to argue for more broad-scale reforms that move away from competition with offshore least-cost producers in basic commodity markets.

For the time being, the Government of New Brunswick has decided to proceed by modifying the existing framework for forest management and planning, rather than undergoing a full-scale tenure reform and re-allocation of the forest. However, given the public pressure demonstrated in both the recent wood supply debate, and the protected areas debate before that, it is clear to the NBDNR that maintaining the status quo of the 1980s and 1990s is no longer an option. Two recent provincial governments have followed through on recommendations made by the Legislative Select Committee on Wood Supply.

The work of the New Brunswick Forestry Task Force is ongoing and results are expected in the current calendar year (2007). The Task Force is, in itself, perhaps a microcosm for how forest policy may be developed in the province in the future. It combines a small number of stakeholder participants doing the bulk of the work, hashing out issues and debating values and trade-offs. The Task Force process also involved a larger number of stakeholders that attended a series of initial workshops to identify indicators. The Task Force is headed by a well-respected expert in forest estate modeling that will run the timber supply analysis. The results of the Task Force will not provide definitive answers, however, but rather present a number of scenarios along with the trade-offs inherent in these potential courses of action. Timber supply is one variable of concern in the different strategies but in this analysis implications for all 15 commercial species in the province will be laid out. As well, other forest values and the degree to which they will be provided under different scenarios will be part of the Task Force report.

By the end of 2007 the Government of New Brunswick will have the Task Force's findings and a report from a random sample survey that solicited information from 2500 provincial residents. With this information in hand, the government will choose whether to obtain further public input on the range of choices and trade-offs available, or to make a policy decision based on the information gathered to date. What is clear is that the province is willing to engage and is in fact actively seeking out scientific, economic and values-based data for determining forest policy in New Brunswick in 2007. Some of the best minds in ecosystem management argue that just such a marriage between disparate and difficult-to-compare information is what is needed for insightful, forwardthinking forest policy.

\section{References}

Adamowicz, W. 2003. Economic indicators of sustainable forest management: theory versus practice. Journal of Forest Economics 9: 27-40.

APEC. 2003. The New Brunswick forest industry: the potential economic impact of proposals to increase the wood supply. Report prepared by the Atlantic Provinces Economic Council for the New Brunswick Forest Products Association. Available at http:// www.gnb.ca/0078/APEC-e.pdf [Accessed April 2005].

Baskerville, G. 1976. Report of the Task Force for evaluation of budworm control alternatives. New Brunswick. Task Force for Evaluation of Budworm Control Alternatives. Prepared for the
Cabinet Committee on Economic Development, Province of New Brunswick.

Baskerville, G. 1995. The forestry problem: Adaptive lurches of renewal. In L.H. Gunderson, C.S. Holling and S.S. Light (eds.). Barriers and Bridges to the Renewal of Ecosystems and Institutions. pp. 37-102. Columbia University Press, New York.

Beckley, T.M., J. Parkins and R.C. Stedman. 2002. Measuring sustainability in forest-based communities: Social indicators research in the Canadian Model Forest Program. The Forestry Chronicle 78: 626-636.

Erdle, T. 1998. Progress towards sustainable forest management : Insight from the New Brunswick experience. The Forestry Chronicle 74(3): 378-384

Erdle, T. and D.A. Maclean. 2005. Forest management in New Brunswick: Jaakko Pöyry study, the Legislative Select Committee on wood supply, and where do we go from here? The Forestry Chronicle 81(1): 92-96.

Gardner Pinfold Consulting. (2000). Socio-economic analysis for the protected areas strategy. Report prepared for the Department of Natural Resources and Energy, Government of New Brunswick, New Brunswick.

Jaakko Pöyry (JP). 2002. New Brunswick Crown forests: assessment of stewardship and management. Report prepared by Jaakko Pöyry Consulting for the New Brunswick Department of Natural Resource and the New Brunswick Forest Products Association. Fredericton, NB. Available at www.gnb.ca/0078/reports/jpmc.asp [Accessed in September 2005].

Kennedy, M., V. Lantz and D. Maclean. 2007. Forest and economic impacts of alternative management strategies on Crown land in New Brunswick. Canadian Journal of Forest Research (in press).

LANB. 2004. Select Committee on Wood Supply: Final Report on Wood Supply in New Brunswick, First Session, Fifty-fifth Legislature. Report prepared by the Legislative Assembly of New Brunswick. Available at: http://www.gnb.ca/legis/business/committees/reports/Wood/legwoodfinal-e.pdf [Accessed March 2005].

Maclean, D.A., K.P. Beaton, K.B. Porter, W.E. MacKinnon and M. Budd. 2002. Potential wood supply losses to spruce budworm in New Brunswick estimated using the Spruce Budworm Decision Support System. The Forestry Chronicle 78: 739-750.

Maclean, D.A., T.A, Erdle, W.E. MacKinnon, K.B. Porter, K.P. Beaton, G. Cormier, S. Morehouse and M. Budd. 2001. The spruce budworm decision support system: forest protection planning to sustain long-term wood supply. Canadian Journal of Forest Research 31: 1742-1757.

New Brunswick Department of Natural Resources (NBDNR). 1982. Introducing a new era of Crown forest management in New Brunswick; The Crown lands and Forest Act. New Brunswick Department of Natural Resources, Fredericton, NB.

1999. Public Hearings. New Brunswick Department of Natural Resources. Crown lands Branch, Fredericton, NB. Available at http://www.gnb.ca/0078/publications/ProtectedAreas-e.asp [Accessed September 2005].

2003. Protected natural areas: our heritage. New Brunswick Department of Natural Resources. Crown lands Branch, Fredericton, NB. Available at http://www.gnb.ca/0078/publications/ProtectedAreas-e.asp [Accessed September 2005].

2005a. New Brunswick Task Force on Wood Supply to conduct fieldwork. Available at http://www.gnb.ca/cnb/news/nr/2006e 0640nr.htm [Accessed March 2007].

2005b. Natural Resources Minister meets with forest management committee. Available at http://www.gnb.ca/cnb/news/nr/ 2005e1640nr.htm [Accessed March 2007].

2006. State of the forest report, 2006. Available at http:// www.gnb.ca/0079/ForestReport-e.asp [Accessed March 2007].

. 2007. Public survey launched on forest management.

Available at http://www.gnb.ca/cnb/news/nr/2007e0389nr.htm [Accessed April 2007]. 